\title{
Editorial da Faculdade de Odontologia
}

Direção da Faculdade de Odontologia da UFRGS tem muito orgulho de estar finalizando seu período de administração consciente de ter cumprido o compromisso de priorizar o ensino de graduação.

Assim, com os recursos obtidos através do Programa de Educação continuada e da implementação de vários cursos de Pós-graduação, os ambulatórios e laboratórios da Faculdade foram modernizados.

Estamos nesta fase final ultimando a reforma do auditório da Faculdade, equipado, inclusive com sistema de microcâmeras e projeção em telão, que irá permitir a realização de cursos teóricos-práticos.

Além disso, a manutenção da periodicidade da Revista da Faculdade nestes quase quatro anos é outro fato que nos orgulhamos, mas para que isto fosse possivel, contamos com a colaboração da Sobracom, cuja parceria nestas publicações muito nos honrou.

Direção da F.O. - UFRGS

\section{Ortodontia e Ortopedia - O desafio de uma mudança de paradigma}

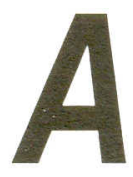

mudança de paradigma não é nova na Odontologia. Os adultos de hoje de meia idade e de classe média tem quase todos os seus dentes restantes obturados com amalgama de prata enquanto que seus filhos apresentam uma dentadura limpa quase desprovida de restaurações. Trocamos as obrigatórias extensões profiláticas pelas medidas preventivas e o resultado não podia ser melhor. A Ortodontia e a Ortopedia Maxilar caminham a passos largos para uma mudança de paradigma na medida que terão de trocar os ideais ortodônticos de alinhamento dentário pela necessidade de não comprometer a saúde de seus pacientes.

Na década de 80 a medicina se deu conta dos distúrbios do sono onde o ronco e a apnéia obstrutiva do sono passaram a ter notável importância na diminuição da qualidade de vida dos indivíduos que as tinham. A apnéia obstrutiva do sono compromete a duração da fase de sono reparador, o sono REM, onde os batimentos cardíacos caem ao mínimo. As apnéias causam um débito na saturação sanguínea de oxigênio obrigando o coração a trabalhar com esforço quando deveria estar em repouso o que a longo prazo tem funestas conseqüência. Hoje se sabe que o ron$c o$ e as apnéias não são privilégio dos homens de meia idade mas podem também afetar crianças e adolescentes. Regras ortodônticas já antigas preconizam que em casos de apinhamento dos dentes inferiores não se deve expandir o arco dentário porque a distância intercanina não pode ser aumentada sob pena de risco de severa recidiva. Assim, para não se aumentar a distância intercanina ou para se obter incisivos verticalizados no osso alveolar se promove a extração de pré-molares ou mesmo de um incisivo com o objetivo de se conseguir arcos dentários alinhados e estáveis. Com as extrações a mecânica ortodôntica acaba diminuindo o perímetro dos arcos dentários. Diminuir o perímetro dos arcos dentários significa tirar da língua seu espaço funcional. Como a língua não pode diminuir seu tamanho ela então muda de posição da frente para traz diminuindo o espaço da faringe, já que ela é a parede anterior do oro-faringe. A diminuição da via aérea na faringe pode comprometer o fluxo aéreo durante o sono propiciando a ocorrência do ronco e da apnéia obstrutiva do sono. Entre as causas anatômicas que podem facilitar a ocorrência de apnéias obstrutivas do sono está a retrognatia mandibular. Ora é comum em tratamentos ortodônticos a extração de pré-molares superiores para redução de sobressaliencias acentuadas relacionadas com mandibulas retrognáticas. Tal procedimento condena para sempre (salvo posterior tratamento cirúrgico) a manutenção da condição retrognática da mandíbula e por consequência o constrangimento do espaço aéreo posterior pela posição também retrognática da língua, já que a língua acompanha a mandíbula. Não é mais admissivel nos dias que correm terminar um tratamento ortodôntico com a mandíbula numa posição retrognática, porque além do problema respiratório que pode ocorrer temos uma condição mecânica de sobrecarga articular sobre as ATM que somente será aliviada pelo reposicionamento mandibular. Ao ortodontista atual é requerido que antes de qualquer cefalometria olhe para o espaço faríngeo em suas teleradiografias e avalie se seu tratamento poderá ou não comprometer esse espaço vital, pois não apenas os retrognatas mandibulares., mas também os indivíduos de mordida aberta, face longa com língua volumosa e hióide baixo no teleperfil fazem parte desse grupo de risco. A mudança de paradigma está em trocar a segurança de dentes alinhado pela preservação do espaço faríngeo abandonando quaisquer procedimentos terapêticos que possam comprometer a qualidade de vida presente e futura de seus pacientes, mesmo que isso possa significar finalizações com dentes menos alinhados. 